AnTard, 26, 2018, p. 000-000

DOI 10.1484/J.AT.5.112629

\title{
CIVIC ADMINISTRATION IN ILLYRICUM AND THRACE
}

\author{
Efthymios Rizos
}

\section{Le gouvernement des cités de l'Illyricum et de Thrace}

\begin{abstract}
Dans les Balkans, les changements dans la vie institutionnelle des cités sont attestés de diverses manières. Dans les provinces du Bas-Danube, des inscriptions de Novae et de Tropaeum indiquent que les titres des anciens municipia ont été remplacés par le titre de civitas/polis, un changement symbolique qui reflétait les réformes administratives tétrarchiques et qui accompagnait des transformations plus profondes en matière d'urbanisme. La construction de cités nouvelles, comme Tropaeum ou Cabyle, représente l'émergence d'une forme de communauté étroitement associée à l'armée et aux structures du gouvernement impérial. Les édifices publics de ces cités ne comprennent que des fortifications et dépôts militaires. Cette impression est confirmée par un document épigraphique de Cabyle en Thrace, qui mentionne la participation de dekaprotoi/ decemprimi (chefs décurions) et du logistes/curator civitatis de la cité à l'administration d'un gynaeceum, une manufacture impériale. Ce document, datant de 309/310, donne une attestation précieuse de la structure d'un conseil municipal dans les premières années suivant la réforme tétrarchique.

L'Illyricum nous offre plusieurs attestions épigraphiques de la fonction de defensor ou patronus civitatis/ekdikos. Cette fonction surtout juridique semble être établie dans la première moitié du Iv siècle et, comme celle du curator, elle doit aussi avoir été principalement ouverte à l'élite équestre. La première attestation du defensor dans le Code Theodosien en 364 interdit l'élection de décurions à cette charge, ce qui semble renvoyer à des irrégularités observées particulièrement en Illyricum. En principe, les defensores attestés par l'épigraphie semblent avoir été d'anciens officiels impériaux de rang équestre. Parmi les activités de ces magistrats, on trouve des actes d'évergétisme, surtout dans les communautés traditionnelles de l'Achaïe, mais aussi la liaison avec les autorités fiscales du gouvernement impérial et la collecte des impôts.

Un cas particulier parmi les cités de la région est Thessalonique, siège de l'administration préfectorale d'Illyricum. Il semble que les Préfets du Prétoire d'Illyricum jouaient un rôle dans le gouvernement de leur capitale, analogue au rôle du Préfet urbain de Constantinople. Aux VI et vII siècles, le pouvoir dans cette cité semble avoir été principalement aux mains de la Préfecture et de l'archevêché. En ce sens, Thessalonique reflétait la fin d'un processus d'expansion de la puissance de l'Église et du gouvernement central, s’imposant au pouvoir des institutions municipales. [Auteur et Rédaction]
\end{abstract}

The ancient civic traditions of the city of Thasos on the homonymous island of the north Aegean were impressively reflected on its splendid late Classical agora with its dignified stoai, civic buildings, shrines, and monuments, all of which were diligently maintained throughout the Hellenistic and Roman imperial periods. On the north side of the civic square, next to the council house (bouleuterion), there stood an elegant small stoa (called 'Building with Paraskenia' by the excavators), on the walls of which one could read a continuous list of the names of the chief magistrates (the eponymoi archontes) of the city from the Classical, Hellenistic and Roman periods, and also letters exchanged by the Thasians with the Senate and powerful men in Rome, including the emperors Nero and Claudius. Nothing seems to have been carved on these walls in the fourth century. The inscribed stones with the names of the archontes were reused as building material in a Christian basilica which 
was built among the ruins of the ancient stoai and council house in the fifth century AD. ${ }^{1}$

The archaeology of the agora of Thasos bears witness to the transformations of the institutions of civic government in Late Antiquity. The instability of the third century and the subsequent administrative reforms of the Tetrarchy probably caused a greater disruption to the civic traditions of this ancient polis than the Roman conquest had done some centuries earlier. With the Tetrarchic administrative reforms, the eponymous archonship and other institutions of the Hellenic poliad tradition, which the Roman Republic and early Empire had allowed to continue as the basis of local government in the Greek East, were abolished and replaced by new institutions and offices. In its turn, this system of administration had to face the decline of municipal financial autonomy in the fourth century and the rise of other sources of power, namely the imperial bureaucracy and the Christian clergy.

\section{From municipium to civitas in the Danube provinces}

For many communities, especially in the central and northern Balkans, the transition into the new era was not peaceful. Near the trophy of Trajan in Moesia Inferior, there was a small town, founded in the late second century AD, the municipium of Tropaeum Traiani (Adamclisi, Romania). ${ }^{2}$ During the third-century wars, the settlement was destroyed and probably abandoned for some time, until it was replaced by a new, substantially enlarged and heavily fortified town, built by the imperial authorities in the 310s. In 316, two important men, Petronius Annianus, Praetorian Prefect of the West, representing the Augustus Constantine, and Iulius Iulianus, Praetorian Prefect of the East, representing the Augustus Licinius, met at Tropaeum, in order to celebrate the dedication of the newly rebuilt town. An inscription above the east gate proclaimed that

[...] for the support of the defence of the frontier, also the city of Tropaeum was built from its foundations, after an auspiciously launched work [...].

[...] ad confirmandam limitis tutelam etiam / Tropaeensium civitas auspicato a fundamentis / feliciter opere constructa est $[\ldots] .^{3}$

1. Grandjean, Salviat 2000, pp. 66-67, 77-78; Chronique 1951, pp. 154164 (Ch. Delvoye). On the inscription, see: Bernard, Salviat, 1962, pp. 578-583.

2. On the municipium of Tropaeum: Tatscheva 2005, pp. 211-217.

3. CIL III, $13734=$ ILS $8938=$ ISCM, IV, $16=$ HD 028858 (last update: 26 June 2013, Feraudi) (my translation).
One should note that the community is no more called a municipium, but a civitas. In a similar manner, the civilian community (municipium) of the legionary base of Novae in Moesia Inferior is attested as $\dot{\eta} \lambda \alpha \mu \pi \rho \alpha \dot{~ N o ß \eta \sigma i ́ \omega v ~ \pi o ́ ~} \lambda_{1 \varsigma}$ in the fourth century, ${ }^{4}$ while the newly designated city of Kabyle in central Thrace is similarly called $\dot{\eta} \lambda \alpha \mu \pi \rho \dot{\alpha}$

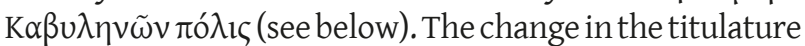
of civic communities in this period reflects the transformations of municipal government and the simplification of the old hierarchies of honour. The old distinctions

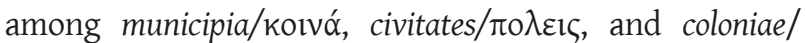

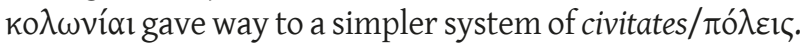

The claim that Tropaeum was built a fundamentis was partly true. Virtually nothing of the old town had been left standing, and the new settlement built under the Tetrarchs was twice as large in extent. Tropaeum was designed as a supporting settlement for the military system of the frontier (ad confirmandam limitis tutelam), a role indicated by the infrastructure of the late Roman town. It was a mightily fortified settlement with a massive public warehouse (horreum) in the centre. No forum or other civic building has been found so far. Tropaeum was an important element of the defence and military supply network in the Danube provinces, and it belonged to a network of heavily fortified towns of the early fourth century, some of which are known to have replaced early Roman municipia, like Abrittus (Razgrad, Bulgaria) and Gorsium (Tác, Hungary). ${ }^{5}$ None of these places has produced evidence for civic buildings of the early Roman tradition, but many of them seem to have had large villa-like residences and massive public warehouses, reflecting the presence of a new administrative system, closely associated with the bureaucracy and fiscal machine of the imperial government. Fourthcentury horrea have been found at central locations of several cities in the northern Balkans, such as the already mentioned Tropaeum, but also at the cities of Zaldapa, Abrittus, Nicopolis ad Istrum, Serdica, Scupi, Sirmium, Kabyle, and Maronea. One can single out the fourthcentury horrea of Nicopolis ad Istrum, which took over a part of the then still functional monumental early Roman agora, thus reflecting the impact of the new fiscal institutions upon the life of the local civic community. ${ }^{6}$

\section{Civic officials of Kabyle in Thrace (AD 309/310)}

The Tetrarchic reforms of provincial administration were based on the understanding of cities as units in the fiscal machine of the state. A number of inscriptions from

\footnotetext{
4. Łajtar 2013, pp. 97-111, esp. 94, 104. On Kabyle, infra, n. 8.

5. Rizos 2017, pp. 19-38, esp. 24-27.

6. Rizos 2013, pp. 659-696, esp. 673-679.
} 
central and southern Thrace mention the drawing of new territorial boundaries among towns and villages under the Tetrarchs. ${ }^{7}$ This activity also included the creation of some new towns in hitherto scarcely urbanised areas, one of which was the revived city of Kabyle in central Thrace - a pre-Roman town which had been dissolved after the Roman conquest of AD 46. After almost three centuries of existence as an auxiliary fort, it was declared a town again and fortified in AD 297. Just like other new cities of the time, Kabyle received no forum or temples at the time of its foundation, but only walls and a large horreum towering in the middle of the settlement. ${ }^{8}$ Yet, unlike the other new towns of the Tetrarchic period, about whose municipal institutions we have virtually no information, Kabyle has produced an inscription, recently republished with an improved reading by Nikolai Sharankov, which throws some light onto both the local government of the town and its role in the political economy of the Tetrarchic empire. Dating from AD 309/310, this inscription is the earliest document reflecting some of the structure of a local municipal authority in the Balkans after the Tetrarchic administrative reforms: ${ }^{9}$

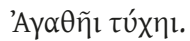

'Yđì

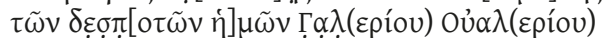
$M \alpha[\xi \iota \mu \nu \alpha] \underline{0} \tilde{0}$

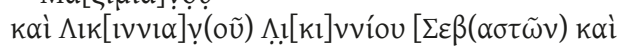

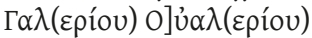

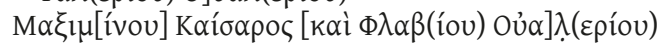

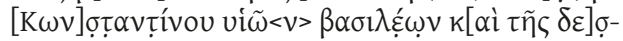

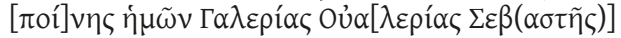

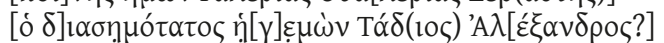

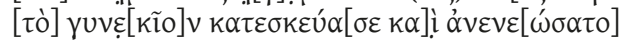

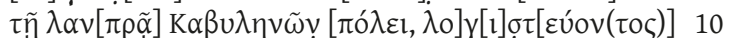

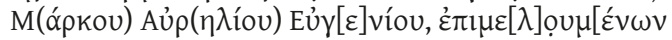
Aủp( $\eta \lambda i ́ \omega v)$ 'Iov?]-

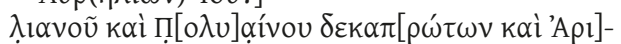

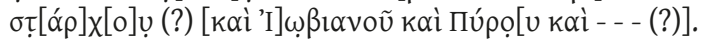

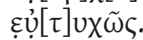

To good fortune.

To the health, victory, and eternal endurance of our sovereign lords, Galerius Valerius Maximianus, and Licinius Licinianus, Augusti, and Galerius Valerius Maximinus, Caesar, and Flavius Valerius Constantinus, Sons of the Emperors, and of our sovereign lady Galeria Valeria Augusta. The diasemotatos/perfectissimus governor Tadius Alexander built and renovated for the splendid city of Kabyle the gynaeceum. Marcus Aurelius Eugenius was logistes/curator. The Aurelii Ioulianos and Polyainos, dekaprotoi/decemprimi, were epimeletai/ procuratores, and Aristarchos and Iovianos and Pyrrhos and [...]. May it be fortunate.

7. $A E 2005,1362=$ HD 065163; $A E 2005,1363=$ HD 065164 (last update: 16 June 2015, Cowey).

8. Sharankov 2017, pp. 199-243, esp. 228-237.

9. Ibidem.
The text reports that the new city, under the title $\dot{\eta}$

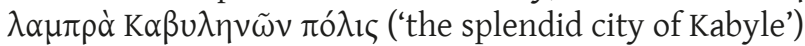
hosted an imperial weaving factory (gynaeceum). This was an important unit of the imperial fiscal apparatus, which, according to the Notitia Dignitatum and the Theodosian Code, belonged to the jurisdiction of the imperial exchequer (comes sacrarum largitionum). ${ }^{10}$ The production of clothing for the army and the civil service at the gynaecea was a part of the taxes in kind requisitioned from certain provinces. In 377 , the fiscal obligations of Thrace included the procurement of one military outfit for each twenty iuga or capita, with the exception of Moesia Inferior and Scythia Minor which paid less on account of their hardships at that time - one outfit per thirty tax units. ${ }^{11}$ Kabyle was apparently one of the places where these clothes were produced; another gynaeceum is epigraphically attested at Perinthus. ${ }^{12}$ The Notitia Dignitatum gives no details about the locations of state factories in the East, but lists fifteen gynaecea in the Western Empire, demonstrating their close association with the military areas. ${ }^{13}$ The newly-documented gynaeceum of Kabyle certainly fits with this pattern, since it was in the vicinity of the Lower Danube frontier.

The renovation of the gynaeceum of Kabyle took place under the auspices of the provincial governor of Thrace, and under the supervision of a number of local dignitaries, including two epimeletai, i.e. procuratores. A decree of 333 held procuratores responsible for the proper management of gynaecea and for the quality of their products. ${ }^{14}$ According to the Notitia Dignitatum, the enterprises of the sacrae largitiones managed by procurators also included fulleries, linen-weaveries, the carriage service, mines, and mints. ${ }^{15}$ In 386 , the threat of barbarian invasion led to the abandonment of imperial mines in north Illyricum by their procuratores who were decurions recruited from the councils of the local cities - conceivably places like Naissus and Ulpiana. ${ }^{16}$ In 377 , a municipal magistrate of Hadrianople attempted to mobilise the workers of the local weapons factory against a contingent of Gothic soldiers, precipitating a counterattack and siege of the city by Fritigern. ${ }^{17}$ Ammianus Marcellinus calls him just magistratus. It is likely that he was either a decurion serving as procurator or the curator/logistes of the city. He was apparently a wealthy and influential man, since he owned land and had a villa near the city, which the Goths had pillaged.

10. Jones 1973, p. 836

11. CTh VII, $6,3$.

12. Wild 1976, pp. 51-58

13. ND Occ. XI; Or. XIII.

14. CTh I, 32, 1 .

15. ND Or. XIII.

16. CTh I, 32, 5 .

17. Amm Marc. XXXI, 6, 1-3. 
According to the inscription of the gynaeceum, the two epimeletai/procuratores of Kabyle were also dekaprotoi. This title is widely attested in the early Roman East as denoting the office of a tax collector, and it is debated whether the Eastern dekaprotoi were a direct equivalent of the Western decemprimi, a committee of leading decurions ${ }^{18}$ This uncertainty applies mainly to the early Roman period, because documents from the Tetrarchic period and the early fourth century suggest that, at least after the reforms of Diocletian, the dekaprotoi were a commission of leading decurions, who are variously mentioned as principales, decemprimi, or dekaprotoi in Sicily and Africa. ${ }^{19}$ The inscription of Kabyle demonstrates that this was the case in Thrace as well. A law of 331 reveals that procuratorships were open only to leading decurions who had successfully performed all other liturgies, i.e. principales/dekaprotoi. ${ }^{20}$ Another law, of 387, informs us that some procurators had the equestrian title of perfectissimus, ${ }^{21}$ which is confirmed by an inscription from Thessalonike where we hear that this was the rank of the procurator of the local imperial mint. ${ }^{22}$ An early fourth-century inscription from Sicily informs us that the same rank could be held by dekaprotoi. ${ }^{23}$ Combined, these testimonies can lead to the conclusion that the cities had a leading commission of decurions, the decemprimi/dekaprotoi, who were eligible for jobs in the imperial service, such as procuratorships. This was the threshold for decurions to be promoted to ranks above their class.

It is unknown whether the procuratores - decemprimi of Kabyle were equestrian, but it seems that they ranked below the highest dignitary in the city, the logistes/ curator civitatis Markos Aurelios Eugenios. His tria nomina suggest that his rank was equestrian or higher. This agrees with what we know about the high profile of his office in the early stages of its existence: in the early fourth century, high-ranking imperial officials were appointed to municipal curatorships. ${ }^{24}$ This office is thought to have been established by Diocletian, probably alongside the tax collecting office of exactor civitatis and the judicial one of defensor civitatis. The inscription of Kabyle is one of the earliest dated attestations of the municipal curatorship outside Egypt. ${ }^{25}$

18. Sideris 2013, pp. 54-74, esp. 62-64 (with an overview of bibliography). 19. Ibidem, p. 60-61; Jones 1973, pp. 730-731; Sharankov 2017, p. 237; P. Cair. Isid. 38.

20. CTh XII, $1,20$.

21. CTh I, 32,6 .

22. Feissel 1983, Cat. Nr. 86.

23. IGUR I, $60=$ IG XIV, 1078a = ILS 8843

24. Frakes 2001, p. 69 (with references to earlier bibliography).

25. Jones 1973, pp. 726-727; Frakes 2001, pp. 40, 68-70. The first attestation of municipal curatores is a papyrus of AD 303 (P. Oxy. LIV, 3727).

\section{The defensor civitatis in Illyricum}

In 364/368, Valens and Valentinian prohibited the appointment of decurions as patroni/defensores civitatum in Illyricum, ordering that these magistrates should be chosen only among former members of the higher ranks of imperial administration (consulares, praesides, palatini, agentes in rebus, vicarii, scholastici). The law stressed that the defensor should be a person able to defend the plebeians against the abuses of the powerful. ${ }^{26}$ The implementation of this law is probably echoed in an inscription honouring the lamprotatos/clarissimus Memmius Pontius Ptolemaeus Parnasius, patronus ( $\pi \alpha \dot{\tau} \tau \rho \omega v)$ of the city of Corinth. Parnasius was the son of a notable pagan family from Patrae with holdings in Corinth. He served as Prefect of Egypt in 357-359, when he was accused of treason, convicted and exiled. By 363 , probably under Julian the Apostate, he was restored his home and property and was allowed to settle in Corinth. ${ }^{27}$ The inscription suggests that he was elected patronus of the city, in perfect agreement with and perhaps under the influence of the rulings of $364 / 368$.

The three rescripts of Valens and Valentinian are the first attestation of the office of defensor civitatis in the legal sources, and were for long regarded as signalling the office's original establishment. Yet, as Robert Frakes has convincingly shown, what they reflect is probably the evolution of a pre-existing office rather than the establishment of a new one. ${ }^{28}$ Frakes argues that, although addressed to the Praetorian Prefect of Illyricum, the three decrees of 364/368 were in fact valid for the whole empire - thus opposing Vincenzo Mannino's earlier view that the rise of the defensor was the result of separate local developments in different parts of the empire, starting from Illyricum and spreading to Italy, Gaul, and elsewhere. ${ }^{29}$ Yet there are reasons to believe that late Roman municipal administration, even though based on empire-wide patterns established under the Tetrarchs, admitted local variation in its evolution during the fourth century. The laws of 364/368 could very well reflect a reform of the defensorship specific for Illyricum, or an effort to rectify irregularities in the function of the office in that part of the empire only.

The first of these three rescripts explicitly limits its scope to Illyricum. Besides, there is another law, precisely from the same years (365/368), which orders that, again exceptionally in Illyricum only, decurions should be replaced by clerks of the imperial administration (apparitores) in their duties as collectors of taxes

\footnotetext{
26. CTh I, 29, 1; I, 29, 3; I, 29, 4.

27. LSA-17 (U. Gehn).

28. Frakes 2001; cf. Mannino 1984.

29. Frakes 2001, pp. 91-92; cf. Mannino 1984, pp.78-91.
} 
in kind (susceptores specierum). ${ }^{30}$ It is possible that this law and the decrees concerning the defensorship were related, and belonged to a reform of municipal administration in Illyricum, focusing on moving power from decurions to members of the civil service. These laws concern two offices which liaised between the municipal and imperial authorities (susceptores and defensores), but the goals of reforming them seem to have differed.

The moving of tax collecting responsibilities from decurions to apparitores is justified in terms of efficiency and reliability, which may be related to conflicts of interest, corruption, and similar obstacles created by the personal connections of decurions in the communities to be taxed. A local councillor could not be expected to act as an impartial tax collector for his own relatives, friends, and fellow townspeople. There was a need for non-locals to undertake an office prone to conflict, violence, and corruption. In the case of defensores, however, the law talks about the ability of these officials to protect the plebeians, which points to a matter of skills and authority level, linked to social hierarchy. The defensorship was a judicial office, which presupposed some legal training and knowledge of imperial administration and legislation, which men of the curial class did not necessarily possess. ${ }^{31}$ Besides, late Roman legislation tends to understand social justice in terms of patronage - those lower in the social hierarchy can only be protected by those higher up, not by their social peers or by the power of institutions per se. In this logic, the legislator seems to attempt a strengthening of the authority of municipal justice against the elite of equestrian or senatorial landowners who were above the personal authority of curial magistrates, and only recognised the jurisdiction of judges who were their own social peers or seniors. This perhaps explains why the defensorship was not open to any imperial functionary, but only to men of high rank. The purpose was not so much to dissociate the office from local society, but rather to strengthen it against powerful individuals. The means of achieving that was an elevation of the social rank required for appointments.

Animportant attestation of the municipal defensorship, possibly contemporary or earlier than the laws of $364 / 368$, is an inscription recording a letter by the proconsul of Achaea Decius Secundinus to the curator and defensor of the city of Amphissa in Phocis. The letter concerns a case of illicit removal of water from an aqueduct by a local landowner, Hesperius, who, according to Secundinus, "should thank this fortunate occasion and my clemency for the fact that a property which encroached on public water supply is not becoming public itself":

30. CTh XII, 6, 9.

31. Jones 1973, p. 500.
... gratias agente beatitudini temporis et moderationi meae Hesperio, quod fundus qui aquam publicam occupavit publicus non fit ... ${ }^{32}$

Hesperius' property deserved to be confiscated, but it seems that the two leading municipal magistrates of the city could not impose any penalty to him, except as executors of the proconsul's commands. The reason may have been that Hesperius' social rank was higher than theirs, thus requiring the intervention of the provincial governor for what was practically a trivial matter of public order. It is such cases that may have made the employment of important men of high social rank and imperial connections as defensores look expedient.

The laws of 364/368 suggest that decurions had been hitherto widely employed as defensores in Illyricum, which the imperial administration opposed. This, however, does not necessarily mean that all appointments to this office according to the previous arrangement had been curial. The earliest attestation of a probable civic patronus or defensor is the dedicatory inscription of a statue set up at Sparta in honour of the proconsul of Achaea Publius Optatianus in 330-334. The monument was donated by the diasemotatos/vir perfectissimus Markos Aurelios Stephanos,

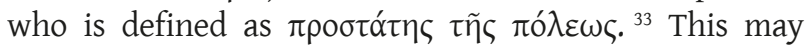
be a literal translation of the Latin patronus or defensor civitatis, which would mean that equestrian officials were appointed to this office as early as the 330s. Stephanos is also defined as a high priest of the imperial cult

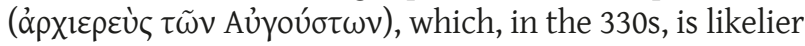
to have been a formerly rather than actually held office. Former priests are mentioned as sacerdotales in the album of Thamugadi, which lists them between the patroni and curator of the city..$^{34}$ This is, to some extent, in line with what the laws of Valens and Valentinian demanded with regard to the defensorship, namely the appointment to the office of retired high officials. It is therefore possible that the admission of men of lower rank to this office was not the rule before 364 , but perhaps the result of administrative laxity or inconsistency in Illyricum.

An inscription from Troezen informs us that "the People of Troezen honoured Theodoros for fostering the city by the wise counsels of his kind protection, but also by his wealth, for he left money for public use by all future generations":

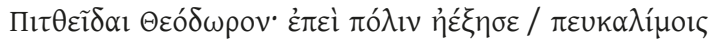

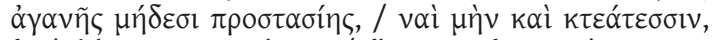

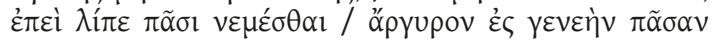

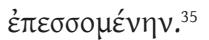

32. CIL III, 568; Mannino 1984, pp. 124-125

33. For text and translation, see LSA-6 (U. Gehn); Robert 1948, p. 21.

34. Jones 1973, p. 730; CIL VIII, $2403=$ CIL VIII, $17824=$ CIL VIII, $17903=$

ILS 6122 = AE 1948, $118=$ HD 021699 (last update 23 February 2006).

35. LSA-600 (U. Gehn); Robert 1948, p. 102. 
Theodoros' office is defined as $\pi \rho \circ \sigma \tau \alpha \sigma i \alpha$, which could be a rendering of defensio civitatis. Similarly, the city of Tegea acclaimed the strong 'defence' it enjoyed from a certain consul Roufos: "Mild and stronghearted defender of the city, consul Rouphos! Defend your Tegea, mighty soul! Defend it against all adversaries!"

”Н

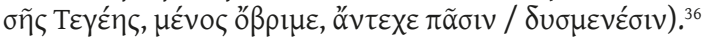

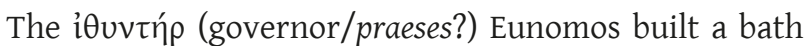
at Naupactus. ${ }^{37}$ The titles of Rouphos/Rufus in Tegea and Eunomos in Naupactus do not need to have been current offices, but also positions formerly held, as the law of 365 demanded for defensores.

A probable defensor of high social standing can be found in the inscription of a statue dedicated to a certain Basilios by the city of Patrae in the Peloponnese. ${ }^{38}$ Basilios held the highest magistracy of the city for five years, which could be the quinquennial defensorship established by Theodosius I in $385 .{ }^{39}$ During that time, Basilios reportedly ran the city on his own, surrounded by a happy and grateful council. The text informs us that he was a member of an old landed family of the Peloponnese with holdings near Pisa in Elis; his father had also been a well-known figure of the local aristocracy. The text does not name his office or social rank, nor does it tell whether he had served in the imperial administration. Yet the man was apparently fabulously rich, since he was able to maintain public baths from his own pocket and to provide for the city ten thousand measures of corn, seventy thousand measures of wine, and eleven thousand measures of oil, from the produce of his estates. A man of such wealth is unlikely to have been a mere decurion. He was one of the local potentes, and must have been at least equestrian in rank. If he was indeed a defensor, it is interesting that his service is not outlined in terms of justice - the defensorship is mainly described as a judicial office in legislation - but rather in terms of patronage. The base of his power was his private residence where he gave generous banquets, treating his guests with personal gifts of gold and clothes. Basilios' inscription demonstrates how personal gifts, which were apparently used for building patronage networks, could be presented as lawful munera.

Aspects of a defensor's social standing and the nature of his daily business are indirectly attested through archaeology, in the so-called House of the ekdikos Georgios at Actia Nicopolis in Epirus Vetus. An extensive and monumental residential complex covering an entire insula of about

36. IG V, 2, 153 .

37. IG IX, 1, 390; Robert 1948, p. 86-87; p. 89.

38. LSA-431 (U. Gehn).

39. CJ I, 55, 4.
$3000 \mathrm{~m}^{2}$, it is believed to have been built as a sumptuous urban mansion in the early imperial period, and remained uninterruptedly in use into Late Antiquity. At some point, possibly in the fourth or fifth century, it was renovated and paved with mosaics which included the dedicatory

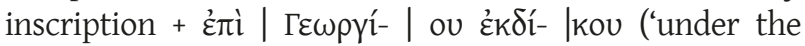
ekdikos Georgios'). The inscription has been interpreted as denoting the owner of the house, but its formulation fits better with the dedication of a public work. It is possible that this fine residence was a house of civic administration, maintained and embellished by the chief magistrates of Nicopolis. It included sumptuous reception rooms and triclinia, where the ekdikos Georgios must have entertained the decurions and other important people in Nicopolis, just like Basilios did at neighbouring Patrae. ${ }^{40}$

The massive donation of corn, wine, and oil by Basilios for the city of Patrae raises the question whether his largesse was in some way associated with the fiscal obligations of the city, or of Basilios' private estates. Patronage and fiscality are aspects reflected in the legislation concerning the defensor civitatis. A law of 383 assigned major landowners, decurions, and small landowners to different tax collecting mechanisms: great landowners were to be taxed by a separate department of provincial administration, decurions by decurions, and small landowners by the defensores. ${ }^{41}$ The latter were also authorised to issue receipts of payment. ${ }^{42}$ Four years later, a decree addressed to the Praetorian Prefect of Illyricum required a decision by the municipal councils for the appointment of defensores, but it prohibited elections by ambitio, i.e. competitive electoral campaigns. ${ }^{43}$ There is no reason to interpret this law as signalling the return of the defensorship to the curial class. What it rather seems to be addressing is abuses in the election of defensores, such as bribery and patronage, which means that, rather than being a burden, the office was attractive to members of the elite, and that the latter used their money and power in order to acquire the support of decurions for their nomination by the city councils - possibly offering banquets and gifts, as Basileios did in Patrae. This is not surprising for an office which apparently provided chances for clientele building and access to the fiscal system of the state. Magnates in Illyricum, in particular, might have had extra reasons to consider the advantages of the defensorship, since, in 383, they were stripped of all the extraordinary tax privileges and exemptions which had accrued to them over the years. ${ }^{44}$

40. Pavlidis 2015 .

41. CTh XI, 7, 12, 383. Admittedly, this law is specifically addressed to the vicar of Pontus.

42. CTh XI, 1, 19, 384.

43. CTh I, 29, 6, 387.

44. CTh XI, 13, 1, 383. 


\section{Euergetism in Achaea and the exceptional case of Athens}

Participation in municipal institutions and acts of euergetism must have preserved a special cultural importance in certain areas. It is probably no coincidence that late antique euergetism is more widely attested in Achaea than anywhere else in the Balkan Peninsula. Besides Basilios of Patrae, benefactions are attested in other neighbouring cities as well. We have already seen the cases of Theodoros who bequeathed money to Troezen and Eunomos who built a bath at Naupactus. Tegea also built a bath with funds provided by a certain Agathon. ${ }^{45}$ Neighbouring Epidaurus honoured Bassos, a member of a major aristocratic family, for his manifold benefactions. ${ }^{46}$ The epigraphy of Achaea preserves the latest attestations of local patriotism and civic pride of Greco-Roman Antiquity.

A remarkable number of honorific inscriptions from the fourth and early fifth centuries comes from Athens. Because of its special historical and cultural importance, this city was allowed to maintain several elements of its Classical constitution, including the Areopagus and the Boule of the Three Hundred (reduced from its original 500 membership). Their survival demonstrates that the city was partly exempted from the Tetrarchic and Constantinian reforms of civic administration, but did the power of the Athenian civic institutions extend beyond the symbolic realm and the ability to confer honours to benefactors $?^{47}$ It would be misguided to assume that it did not. The Athenian institutions were manned by the prosperous local gentry which maintained the city's religious, civic, and academic institutions, undertook public functions and liturgies, and even exerted regional influence by fostering connections with the proconsuls of Achaea and the Praetorian Prefects of Illyricum. What remains hard to understand is the precise nature of the local civic offices. The Athenian magistrates preferred to call themselves by eccentric academic and priestly titles which are completely unattested elsewhere in the fourth century, while common late antique municipal offices are never mentioned in Athenian inscriptions. Among the people honoured in fourth-century Athens, we find Hegeias who was eponymos archon ('eponymous magistrate'), ${ }^{48}$ Ploutarchos who was basileus logon ('king of orations') and mython tamias ('treasurer of orations/ myths'), ${ }^{49}$ Apronianos who was sophistes (sophist), ${ }^{50}$

45. Greek Anthology 16. 280 (text: W.R. Paton, Loeb 84).

46. LSA-579 (U. Gehn).

47. For example, the statue dedicated by the Boule and the Areopagus to proconsul Rufius Festus: LSA-103 (U. Gehn).

48. LSA-102 (U. Gehn).

49. LSA-134, LSA-137 (U. Gehn).

50. LSA-138 (U. Gehn). and Flavios Pompeios who was dadouchos (one of the priesthoods of Eleusis). ${ }^{51}$ Did these titles simply denote academic and religious positions or were they alternative ways of referring to normal late antique civic functions? Besides claiming continuity from ancient archonships, could eponymos archon, basileus and tamias be Classicising ways of referring to what would elsewhere have been called curator/logistes, patronus/defensor/ekdikos, or exactor/strategos? The honorands were usually thanked for what seems to have been normal liturgies like the building of fortifications by a certain Iamblichos - could he have served as the equivalent of a curator or defensor? $?^{52}$

It is, of course, possible that these benefactions were indeed voluntary and unrelated to municipal office. In 413, a law ruled that non-decurions willing to perform curial liturgies out of generosity or patriotism should be admitted to such positions by city councils in Illyricum, without being bound to the hereditary duties and property obligations of the decurionate..$^{53}$ This was yet another exceptional ruling applying to Illyricum only, which was meant to help the cities of the region recover from the effects of recent warfare - conceivably Alaric's campaigns. These patriotic volunteers were, of course, not poor citizens, but wealthy landowners whose willingness to help their communities was deterred by fear that they might become hereditary decurions, if they agreed to perform municipal liturgies. Judging from the epigraphic record, the likeliest part of Illyricum to have had such people must have been Achaea and more specifically Athens.

\section{The impact of imperial fiscality and defence}

An important joint task of the imperial and municipal authorities was the calculation and collection of taxes in kind. This is also reflected in a document of AD 402, known from two fragmentary inscriptions found in Corinth and Megara. ${ }^{54}$ It was a regulation concerning the amounts and time schedule of payments due by the cities of the province, as agreed among their representatives - perhaps the defensores - who had probably convened at the provincial council of Achaea under the proconsul Claudius Varius. ${ }^{55}$ The fact that the payments in question concerned taxation in kind is indicated by the fact that they were expected to be made at the two central imperial horrea of Achaea at Corinth and the Boeotian

51. LSA-103 (U. Gehn).

52. LSA-135 (U. Gehn); Gehn 2016, pp. 195-196.

53. CTh XII, $1,177$.

54. IG VII, 24 = SEG 40, 402 (Megara); SEG 42, 262 (Corinth). Sironen 1992 , pp. 224-226; Rizos 2015, pp. 287-302, esp. 296-297.

55 . The meetings of provincial councils were regulated by a decree addressed to the Praetorian Prefect of Illyricum and Africa Apodemius (CTh XII, 12, 13, 392). 
port-town of Skarpheia, serving the Peloponnese and mainland Greece respectively. The text attests to the great importance of imperial warehouses (horrea) as the built infrastructure of the fiscal machine of the state, which, as we saw above, are amply attested through archaeology in the northern Balkans. The horrea were under the jurisdiction of the imperial administration and run by officials known as praepositi, whose office (praepos-

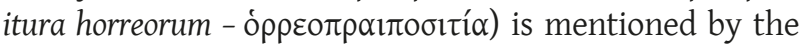
inscription. A law of AD 412, concerning Illyricum, reveals that curial procuratores were also involved in managing public horrea, and in procuring from them goods as subsistence allowances in kind for members of the provincial administration and the army. Yet it appears that this was not a part of their officially prescribed duties, and the law prohibits it. ${ }^{56}$ Much like the earlier decree against the employment of decurions as tax collectors, there appears to have been a consensus among lawmakers that the curial class should be kept away from the fiscal goods of the imperial government.

One of the main recipients of fiscal goods collected in kind was the army. The fourth-century warehouses were the built infrastructure of the provisioning network of the annona militaris, and their presence in the cities embodied the close interaction and interdependence between the cities and the army. This was a result of the wars of the third century, and warfare was a major generator of change in civic life throughout Late Antiquity. Besides the appearance of horrea and tax collecting mechanisms, a universal consequence of the recurrent lapses into insecurity was the gradual militarisation of urban life, especially through the building of fortifications.

Intensive fortifying activity is observed throughout the central and northern Balkans already in the mid-third century and, by the early fifth, even the southernmost cities of Illyricum in Achaea had to be fortified. Many cities were compelled to build or repair their walls for the first time since the Roman conquest. Defensive building drives were probably directed by the imperial authorities, but locally implemented by the city councils. The city of Megara in Attica honoured the Praetorian Prefect of Illyricum Herculius (fl. 408-412) for repairing its walls and an aqueduct, and a certain Phosphorius, very probably proconsul of Achaea, for his role in fortifying the cities of the province. ${ }^{57}$ Defensive building projects entailed great burdens for local communities. The contribution to the erection of walls was a compulsory service, demanded in accordance to one's land and tax units. As with other forms of taxation and state service, exemptions and

56. CTh VII, 4, 32, 412 .

57. IG VII, 93; IG VII, 96. privileges were awarded also with regard to this, but two laws of 408/412, exceptionally issued for Illyricum only, ordered that all exemptions concerning defensive building, which had been awarded to notables in this prefecture, should be cancelled: everyone regardless of social standing had to contribute to the construction of walls in Illyricum. ${ }^{58}$ This ruling seems to have had some effect, and defensive building was even included in the rhetoric of euergestism. Megara dedicated a monument to a wealthy aristocrat called Diogenes (fl. 472-494) who sponsored the construction of towers and a bathhouse in the city, alongside many other building projects in cities of Greece. ${ }^{59}$ Diogenes, one of the latest recorded civic benefactors in our region, appears to have been a member of the local aristocracy, bearing the equestrian title of a megaloprepestatos and the military one of a comes. Militarisation affected not only the agenda of building, but also the character and composition of the elite.

The threats and dangers of war often tested the loyalties of local communities, but also provided chances for them to choose their connections and position in the landscapes of power. In the 320s, the Thracian city of Augusta Traiana (Stara Zagora, Bulgaria) set up a statue in honour of the emperor Constantine, probably following his final victory over Licinius. Several cities honoured the triumphant emperor with monuments, but the dedication of Augusta Traiana stands out by its hyperbolic praise of Constantine's presumably bloodless victories (“... him who was crowned with his victories from West to East with absolutely no shedding of blood"

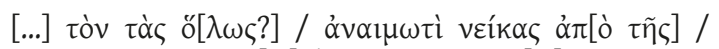

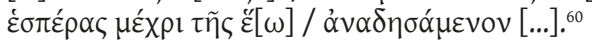

The phrase reads as if the notables of the city thanked the emperor for sparing their lives. Augusta Traiana Beroe very probably had sided with Licinius during the war, and its thanks to the victorious Constantine may reflect the dilemmas and risks it had faced. Some 150 years later, the same city set up a monument to the Gothic patrician Aspar, ${ }^{61}$ while neighbouring Philippopolis (Plovdiv) honoured the later usurper Basiliscus. ${ }^{62}$ Both of these powerful men had close connections to the military forces and communities of Thrace. We can only guess how these links affected the locals after the murder of Aspar in 471 and the usurpation of Basiliscus (475-476). During the Gothic invasion of $379 / 380$, Nicopolis ad Istrum decided to stop waiting for protection from the imperial army, and to organize its own defence. Eunapius refers to

58. CTh XII, 17, 4, $408=$ CTh XV, 1, 49, 412 .

59. IG VII, 26.

60. LSA-1665 (U. Gehn). Reading and translation slightly adapted by me. 61. LSA-10 (U. Gehn). 62. LSA-367 (U. Gehn). 
the decision with a mixture of admiration and mistrust: "scorning those who were unable to defend themselves, they opted for a precarious independence". ${ }^{63}$ Almost one century later, the people of Thessalonike, suspecting that the emperor Zeno and the Praetorian Prefect of Illyricum were secretly planning to surrender their city to the invading Goths, revolted and, having destroyed the imperial statues, they assaulted the prefect himself. The riot was only prevented by the intervention of the

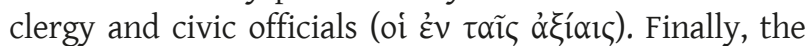
citizens took the keys of the city gates from the prefect, and handed them to their bishop. ${ }^{64}$

\section{A city with a resident praetorian prefect: Thessalonike}

The administration of Thessalonike, which was the largest city of the Balkan region after Constantinople, seems to have been exceptional among all provincial cities in the region, due to its special role in the imperial administration of the Balkans, ever since the emperor Galerius decided to promote it to one of the centres of the decentralised late empire. It had a palace which remained functional into the early seventh century, probably hosting the headquarters of the vicars of Macedonia and the praetorian prefects of Illyricum. ${ }^{65}$ The archaeologically documented continuity of the life of the palace in Late Antiquity stands in clear contrast with the discontinuity observed in the early Roman agora which had been the base of the civic institutions of Thessalonike since the early imperial period. The agora bears signs of a wideranging renovation in the fourth century, which was apparently interrupted before completion. There are no signs of maintenance during the fifth century and, by the sixth, the site was taken over by kilns and workshops. ${ }^{66}$ The archaeologically documented life-spans of the agora and the palace indirectly reflect the power dynamics between the municipal and prefectural authorities in Thessalonike. It appears that the prefectural administration took over many, though certainly not all, aspects of running the city. Besides acting as a deputy of the emperor and supreme judge in the west and south Balkan provinces, the praetorian prefect of Illyricum seems to have also acted as an urban prefect of his residence city.

The authority of praetorian prefects was in principle judicial, but they were also in charge of urban defence. They probably controlled the troops which defended

63. Eunapius, History, Fr. 47, ed. and transl. Blockley 1983.

64. Malchus, Fr. 20 (Blockley 1983)

65. Athanasiou et alii 1997, pp. 401-416; Athanasiou et alii 1998, pp. 113-

126; Athanasiou et alii 2006, pp. 299-317.

66. Kalavria, Boli 2001, pp. 37-64; Valavanidou 2001, pp. 119-130.
Thessalonike, maintained its walls, and kept, as we saw earlier, the keys of its gates. Two of the few known inscriptions from the late antique walls of the city commemorate praetorian prefects, celebrating this dual, military and judicial, authority:

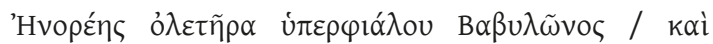

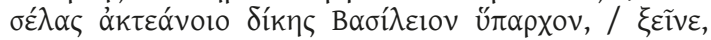

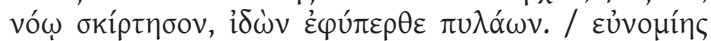

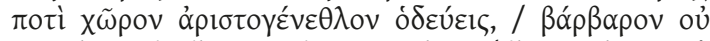

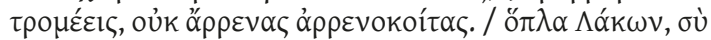

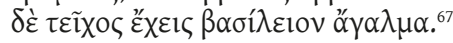

Exult in your mind, stranger, as you see above the gate the Prefect Basileios, destroyer of the valour of insolent Babylon, and beacon of unmercenary justice. You are entering the noble home of the rule of law. You do not need to fear the barbarians or men who sleep with men. A Spartan has his arms, and you an imperial wall to take pride in.

This text, which once accompanied a statue of this prefect, was set up over one of the eastern city gates, very probably the Gate of Cassandrea. Like the gate itself, the inscription has long been lost, but it was recorded in the Greek Anthology. It probably celebrated the completion of a major reinforcement of the walls, built under the supervision of Basileios. The final verse is a pun which allows reading either 'an imperial wall' or 'a wall of Basileios' - the prefect's name literally means 'royal'. It thus indirectly reflects the role of the prefect as the chief of a building project realised in the name of, and with funds from an emperor.

Another inscription, still partially extant on a tower of the eastern walls, commemorates the completion of a major fortification project by the Praetorian Prefect Hormisdas:

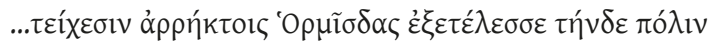

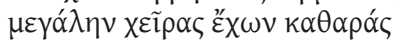

Hormisdas, who had clean hands, accomplished [the work of protecting?] this great city with unbreakable walls. ${ }^{68}$

The inscriptions of both Basileios and Hormisdas focus on the two aspects of the prefects' authority justice without corruption, and defence. Basileios was a "beacon of unmercenary justice," while Hormisdas "had clean hands" - an expression also known from the epitaph of the former proconsul of Achaea and

67. Greek Anthology 9, 686 (my translation). Paton oddly identifies the hyparchos Basileios with the emperor Basil I (AD 867-886) and associates the epigram with his victories in the East. That is very unlikely, however. The reference of the fifth verse to homosexuality ("you do not need to fear the barbarians or men who sleep with men") recalls the events surrounding the massacre of 390 (Sozomen, Ecclesiastical History, 7. 25), though no Praetorian Prefect of Illyricum named Basil is known from that time.

68. SEG 46, 817; Rizos 2011, pp. 450-468, esp. 454. 
Praetorian Prefect Andreas who, "while administering justice in Greece and Illyricum, kept his hands clean of unlawful wealth":

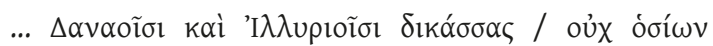

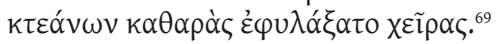

The judicial nature of the prefect's power and praise for his integrity are also prominent in the early seventhcentury Miracles of Saint Demetrius where one Prefect is described as a man "who helmed the reins of justice in a pure and pious manner, thus both pleasing God and enjoying the gratitude of the multitudes"

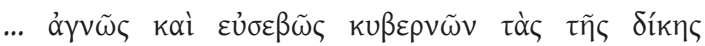

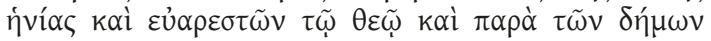

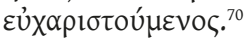

The subjects of this prefect's judicial power are described as $\delta \tilde{\eta}$ uol. Does this just mean 'multitudes', or could its plural form refer to urban associations like demes, circus factions, and professional guilds? Associations were a major domain of civic life in Antiquity, which, after a long period of prominence and documentary visibility under the early Empire, disappeared under a long silence after the fourth century. Yet it certainly continued to exist in some form and played a role in the life of cities, especially major ones like Thessalonike where the regulation of the large local market by the civic government must have involved dealings with professional guilds. ${ }^{71}$ This was, as we know from the Eparch's Book, one of the main tasks of the Urban Prefect in Constantinople, while, at lesser cities like Sardis or Oxyrrhynchus, it appears to have been a responsibility of the local curatores or defensores..$^{72}$ It appears that in Thessalonike this function was performed by the Praetorian Prefect of Illyricum..$^{73}$ This is suggested by a fragmentary sixth-century inscription of what seems to be an imperial rescript which attests to the involvement of the prefect in monitoring imports of worked leather in Thessalonike. ${ }^{74}$ This was apparently an important issue for the trade of leatherworkers, since it is also mentioned in the chapter concerning them in the Constantinopolitan Eparch's Book (ch. 14, $\pi \varepsilon p i$ i $\tilde{\omega} v$ $\lambda \omega \rho o \tau o ́ \mu \omega v)$. Another possible attestation of a professional group in Thessalonike is a seventh/eighth-century dipinto (now lost) from the church of Saint Demetrius,

69. Greek Anthology 7, 672 ; Robert 1948, pp. 72, 86-87.

70. Miracles of Saint Demetrius (Mir. Dem.), I, 1 (10) (ed. Lemerle 1981).

71. Jones 1973, pp. 858-864.

72. Ibidem, p. 859; Grégoire 1922, Nr. 322

73. There is no attestation of a defensor in Thessalonike, and one may wonder whether the office existed at all at the city. To my knowledge, defensores in general are not attested at provincial and diocesan capitals with resident provincial governors, vicars, or prefects. Perhaps the office was unnecessary at the seats of superior judicial authorities.

74. Feissel 1983, Nr 85.

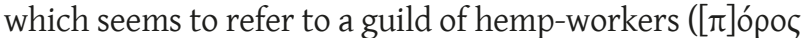
[?] $\tau \tilde{\omega} v \kappa \alpha v \alpha \beta \alpha ́ \delta \omega v) .^{75}$ These two epigraphic documents are possibly the only testimonies of guilds and trades in the early Byzantine Balkans. Besides these, it seems that the Blues and the Greens were also active in Thessalonike. ${ }^{76}$

A market-related field of civic administration, where the prefectural and municipal authorities must have shared responsibility, was corn supply. Thessalonike

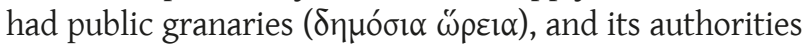
received warnings from Constantinople in periods of food shortages. ${ }^{77}$ Yet, at one such case, the speculative management of the corn deposits by the officials caused the city to be caught in a siege without sufficient food supplies. ${ }^{78}$ The author of the Miracles of Saint Demetrius talks about these officials in very general terms, so that we cannot be entirely confident about their precise institutional status. Yet he interestingly states that "the officials then in charge of administration" included "both aliens and locals"

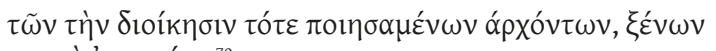

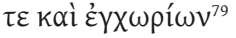

which apparently suggests a combination of local municipal and non-local imperial/prefectural officials.

This bold accusation of corruption against the authorities of the city comes from the hand of a cleric, the anonymous author of the second collection of the Miracles of Saint Demetrius, who very probably belonged to the clergy of the saint's shrine. His strict criticism brings to mind power dynamics familiar from sixth-century sources such as Justinian's Novels 8 and 86 , and the Miracle of Saint Nicholas of Myra (BHG 1349z), all of which refer to abuses by corrupt civic and imperial officials, and present the clergy as a bulwark against the corruption and violence of the secular authorities. The author of the Miracles claims that only Saint Demetrius was able to repel the innumerable ploys and abuses of those in charge of the city's administration, and that it was he who saved the city from famine and sack. ${ }^{80}$ Besides, the saint is portrayed as the invisible custodian of public order in times of general unrest and civil strife, ${ }^{81}$ and as a valiant soldier defending Thessalonike against its enemies. ${ }^{82}$ Although the saint is presented in supernatural terms, it should not escape our attention that the domains of his protective power coincide with the areas of respon-

75. The Cult of Saints in Late Antiquity: E01256 (E. Rizos).

76. IG X, 21 20; Cameron 1976, p. 314.

77. Mir. Dem. II, 4 (244).

78. Mir. Dem. II, 4 (244-282).

79. Mir. Dem. II, 4 (282).

80. Mir. Dem. II, 4 (244-282).

81. Mir. Dem. I, 10 (81-93).

82. Mir. Dem. I, 13 (116-130; 195-214). 
sibility of the civil authorities (public welfare, public order, and defence). Since all the things which the saint was supposed to be doing invisibly, also reflected on his institutional representatives, namely his shrine and the Church of Thessalonike, we may safely conclude that these institutions claimed responsibility in crucial aspects of civic government. The Miracles of Saint Demetrius stand out among the works of hagiography by their pronounced focus on government matters, thus reflecting the attitudes of a politically active bishopric and shrine. The patron martyr not only embodied civic identity, but was also able to counterbalance the overwhelming domination of the imperial authorities over local society. Indeed, at some point, Saint Demetrius was invoked by a group of civic

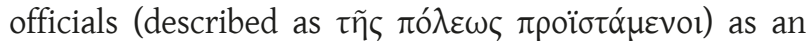
excuse for refusing to fulfil a mission assigned to them by the praetorian prefect. Indignant, the prefect blasphemed against the saint, calling him an accomplice in the ploys of his fellow townsmen. ${ }^{83}$

The political role of the archbishopric of Thessalonike is also reflected in another hagiographical text, the eighthcentury Life of Saint David of Thessalonike (BHG 493), where it is claimed that a Praetorian Prefect of Illyricum requested the mediation of an archbishop of Thessalonike with the emperor Justinian, in order to achieve the transfer of the seat of the prefecture from Sirmium to Thessalonike. The bishop convoked a civic assembly (or council) which decided that the city should send the local holy man David as an envoy to the emperor. According to the text, the bishop could not be sent, lest the city were left ungoverned. The historical accuracy of the event is dubious, since it seems to be conflating two separate historical contexts - the foundation of Justiniana Prima in the 530s and the fall of Sirmium to the Avars in 582 - but, regardless of historical accuracy, the account reflects Thessalonike's perception of itself as a city dominated by the prefectural and ecclesiastical authorities, with the latter emerging as superior.

\section{Bishops run cities}

In the course of the fifth and sixth centuries, it seems that the cities of the Balkans followed the development of local administration towards what Wolfgang Liebeschuetz has described as government by notables under the domination of a powerful episcopate. ${ }^{84}$ Yet the documentation of this development in this region is scanty and limited to generic textual references like those in the hagiographic texts mentioned above, and sporadic epigraphic attestations like two fifth/sixth-century epitaphs of defensores ( $\left.\varepsilon^{\prime} \kappa \delta i \kappa o l\right)$

83. Mir. Dem. I, 10 (96-97). 84. Liebeschuetz 2001. from Macedonia, which provide no information about the responsibilities of these functionaries. ${ }^{85}$

The dominance of episcopal authority in the cities is indirectly reflected in the burgeoning proliferation of ecclesiastical building at virtually every town, especially in the late fifth and the sixth centuries. Justinian's most illustrious building project in the Balkans, the new city of Justiniana Prima, was designed, among others, in order to host the headquarters of a new ecclesiastical authority, the archbishop of Dacia. ${ }^{86}$ Both the account of Procopius and the archaeology of Caričin Grad confirm the dominance of the ecclesiastical authority in the new city ${ }^{87}$ An inscription of unknown provenance, found in Prijepolje in Serbia, celebrates the building of an entire city by a bishop called Stephanus, under Justinian. ${ }^{88}$ Within a few years, Stephanus built walls, churches, houses, fountains, stables, courts, and baths. In the 570s, the bishop of Serdica supervised the rebuilding of an aqueduct and other buildings, with funds provided by the emperor Tiberius Constantine through the mediation of a military official, the candidatus Iulianus. ${ }^{89}$ Also in the sixth century, Epiphanios, bishop of Phthiotic Thebes in Thessaly dedicated a building at his town, which he had built with assistance by two secular officials. ${ }^{90}$ In the beginning of this paper, we saw that cities in the fourth-century Balkans were built by Praetorian Prefects and run by curatores and decurions. Now, we find bishops performing these tasks.

Two novels issued by Justinian in 535 and 538 reflect a significant moment in the rise of the material power of the church in the Balkans. According to them, landowners in the Danube provinces of Moesia Inferior and Scythia abandoned their estates in the countryside on account of the insecurity of the region, and bequeathed or donated their properties to the local bishops. The bishop of Odessus (Varna) requested to be exempted from the imperial ban on the alienation of church property, in order to be able to liquidate bequests which could not be profitably exploited. Justinian allowed him to grant perpetual emphyteutic leases, a right which he extended to all churches in $544 .{ }^{91}$ By this process, it appears that the bishopric of Odessus, and conceivably many other episcopal sees, became a major, if not the greatest, institutional landowner in its city and area.

\section{Linacre College Oxford}

85. Feissel 1983, Nr. 68, 71.

86. Nov. Iust. 11.

87. Proc., Aed. 4.1. 23-25.

88. Feissel 2000, pp. 81-104, Nr. 15.

89. HD 042884 (last update 27 April 2009, Gräf).

90. ICG 3802.

91. Jones 1973, p. 897. Nov. Iust. 45 (535); 45 (538); 120, par. 1, 6 (544). 
BiBLIOGRAPHY*

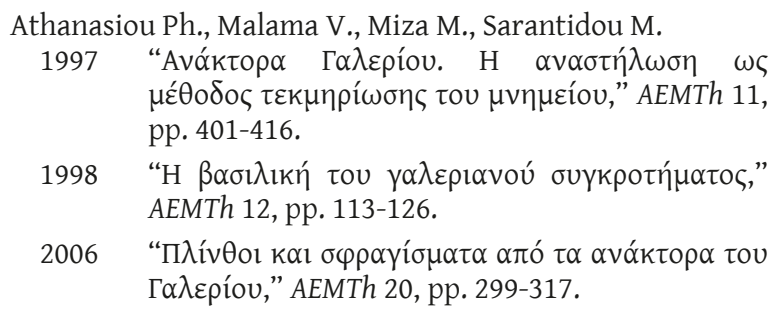

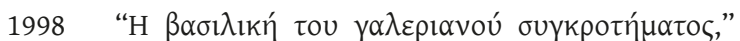
AEMTh 12, pp. 113-126.

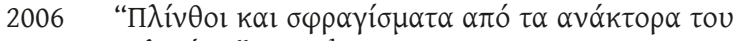

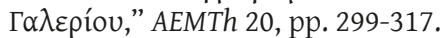

Bernard P., Salviat F.

1962 "Inscriptions de Thasos," BCH 86, pp. 578-611.

Blockley R. C.

1983 The Fragmentary Classicising Historians of the Later Roman Empire, Cambridge.

Cameron A.

1976 Circus Factions: Blues and Greens at Rome and Byzantium, Oxford.

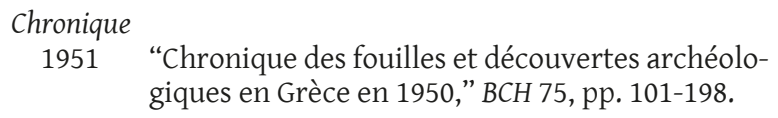

2000 "Les édifices de Justinien au témoignage de Procope et de l'épigraphie," AnTard 8, pp. 81-104.

Frakes R. M.

2001 Contra Potentium Iniurias: The Defensor Civitatis in late Roman Justice, Munich.

Gehn U.

2016 'Athens,' in R.R.R. Smith, B. Ward-Perkins (dir.), The Last Statues of Antiquity, Oxford, pp. 190-199.

Grandjean Y., Salviat F.

2000 Guide de Thasos, Paris.

Grégoire H.

1922 Recueil des inscriptions grecques chrétiennes d'Asie Mineure, Paris.

Kalavria V., Boli A.

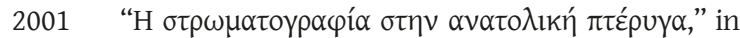

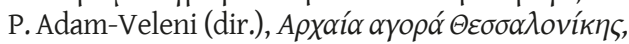
Thessaloniki, pp. 37-64.

Jones A. H. M.

1973 The Later Roman Empire, 284-602: A Social, Economic and Administrative Survey, Oxford.

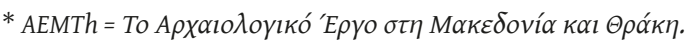

Łajtar A.

2013 "A newly discovered Greek inscription at Novae (Moesia Inferior) associated with pastus militum," Tyche 28, pp. 97-111.

Lemerle $\mathrm{P}$.

1981 Les plus anciens recueils des miracles de Saint Démétrius et la pénétration des Slaves dans les Balkans, Paris.

Liebeschuetz J. H. W. G.

2001 The Decline and Fall of the Roman City, Oxford.

Mannino V.

1984 Ricerche sul Defensor Civitatis, Milano.

Pavlidis E.

2015 Nicopolis. The domus of the Ekdikos Georgios, (Monuments of Nicopolis 5), Athens.

Rizos E.

2011 "The late antique walls of Thessalonica and their place in the development of eastern military architecture,"JRA 24, pp. 450-468.

2013 "Centres of the late Roman military supply network in the Balkans: a survey of horrea,"Jahrbuch des Römisch-Germanischen Zentralmuseums 60, pp. 659-696.

2015 "Remarks on the logistics and infrastructure of the Annona Militaris in eastern Mediterranean and Aegean Areas," AnTard 23, pp. 287-302.

2017 "New cities and new urban ideals, AD 250-350," in E. Rizos (dir.), New Cities in Late Antiquity: Documents and Archaeology (BAT 35), Turnhout, pp. 19-38.

Robert L.

1948 Hellenica IV: Epigrammes du Bas-Empire, Paris.

Sharankov N.

2017 "Inscriptions from Cabyle," Bulgarian E-Journal of Archaeology 7.2, pp. 199-243.

Sideris A

2013 “A dekaprotos from Antikyra," Eirene 49, pp. 54-74.

Sironen E.

1992 "The edict of Diocletian and a Theodosian regulation in Corinth," Hesperia 61, pp. 223-226.

Tatscheva M.

2005 "Die Munizipalisierung in den Provinzen Moesia Superior and Moesia Inferior," in M. Mirković (dir.), Römische Städte und Festungen an der Donau, Beograd, pp. 211-217.

Valavanidou A.

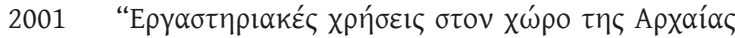

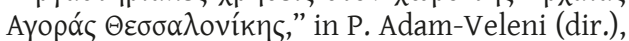

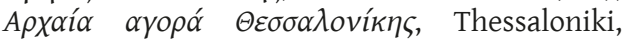
pp. $119-130$ 
Wild J. P.

1976 "Gynaecea," in R. Goodburn, Ph. Bartolomew (dir.), Aspects of the Notitia Dignitatum (British Archaeological Reports, Supplementary Series 15), Oxford, pp. 51-58.

\section{Online databases}

HD Epigraphic Database Heidelberg: https://edhwww.adw.uni-heidelberg.de/data.

ICG Inscriptiones Christianae Graecae: http://repository.edition-topoi.org/collection/ICG.

LSA Last Statues of Antiquity: http://laststatues.classics.ox.ac.uk.

The Cult of Saints in Late Antiquity (University of Oxford 2017): http://csla.history.ox.ac.uk/. 
